\title{
RAPID TITRATION OF RABIES VIRUS INFEGTIVITY BY BIOTIN-AVIDIN-PEROXIDASE TECHNIQUE AND ITS APPLICATION TO VIRUS NEUTRALIZATION TEST
}

\author{
Akehisa Shichijo ${ }^{1}$, Kumato Mifune ${ }^{1}$ And Whei Jun Lin ${ }^{2}$ \\ Received for publication September 241982
}

\begin{abstract}
The rapid titration method of the infectivity and the neutralizing antibody of rabies virus was established by the use of immuno-peroxidase (biotin-avidinperoxidase) staining technique in microslide culture chambers. This method offers high sensitivity and reproducibility and would provide a new mean for the rapid diagnosis of rabies and the seroepidemiology of rabies virus.
\end{abstract}

\section{INTRODUCTION}

Many studies have been reported on the quantitation of infectious rabies virus in vitro (Yoshino et al., 1966; Sedwick and Wiktor, 1967; Matsumoto and Kawai, 1969; Schneider, 1973; Buckley and Tignor, 1975; Strating et al., 1975). However, the plaque titration method can be applied, in general, for only laboratory-passaged virus strains and requires a longer incubation period to obtain the results. In contrast, in fluorescent antibody (FA) technique, rapid and reproducible titration can be attained using the culture cells sensitive to rabies virus and even street strains can be quantitated by counting fluorescent foci on the cells (Smith et al., 1977).

Recent progress of immuno-peroxidase techniques provides a new mean to detect viral antigens in the infected cells (Benjamin, 1974; Miller et al., 1974; Gerna et al., 1976) and to quantitate the infectivity of virus (Hahon et al., 1975; Okuno et al., 1977, 1979). This technique has several advantages when compared with FA technique. The samples can be examined with a light microscope and stored for long time after fixation according to the stability of the staining. Thus if the technique is applicable for virus neutralization test, this should be the most suitable method for determining the neutralizing antibodies against rabies virus of large number of specimens.

Among the immuno-peroxidase techniques, the use of biotin-avidin interaction system has been proved to be highly sensitive for the detection of cell-associated antigens and has been extensively employed for immunohistochemistry (Guesdon et al., 1979; Warnke et al., 1980; Hsu et al., 1982).

Therefore, the present study was begun with an application of biotin-avidinperoxidase (BAP) technique for the infectivity assay of rabies virus and virus neutralization test with an ultimate goal of an application for the immunoelectronmicroscopic studies of the virus.

1 Department of Microbiology, Medical College of Oita, P. O. Box 37, Oita 870-91, Japan

2 Department of Virology, Institute for Tropical Medicine, Nagasaki University 


\section{Materials ANd Methods}

Virus: The plaque purified CVS strain (Buckley and Tignor, 1975) of rabies virus was grown in murine neuroblastoma cells ( $\mathrm{N}-18$ clone) and stored at $-75^{\circ} \mathrm{C}$ until use.

Cells: Murine neuroblastoma cells and CER cells (Smith et al., 1977) were grown in Eagle minimum essential medium (MEM) supplemented with 5\% fetal calf serum and 5\% calf serum and antibiotics. CER cells were used for the infectivity assay of rabies virus throughout the study. Microslide culture chamber (10 chambers, Bellco Glass, Inc. NJ, U. S. A.) (Fig. 1) received $0.25 \mathrm{ml} /$ chamber of cell suspensions at a cell density of $8 \times 10^{4} \mathrm{cells} / \mathrm{ml}$ of medium and the cells were incubated at $37^{\circ} \mathrm{C}$ in $5 \% \mathrm{CO}_{2}$ incubator until the monolayers of the cell completed.

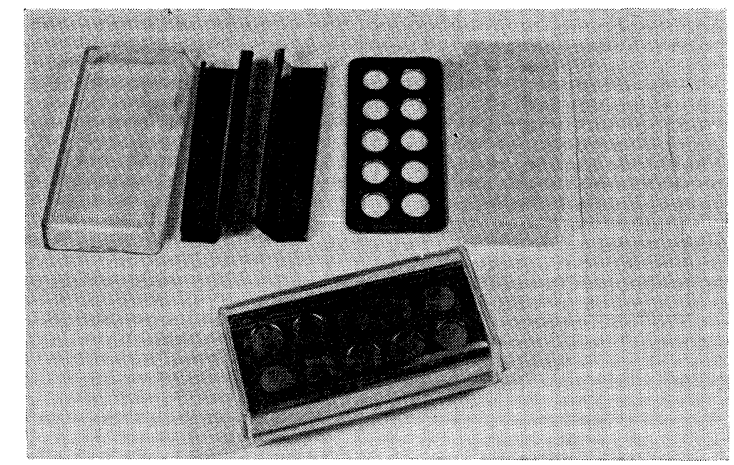

Figure 1 Microslide culture chamber (10 chambers per slide). The culture chamber can be used repeatedly only by changing a bottom slide glass.

staining of the cells by BAP technique: CER cell monolayers on microslide culture chambers were inoculated with $50 \mu 1 /$ chamber of serially diluted virus suspensions and incubated for $90 \mathrm{~min}$ at $37 \mathrm{C}$ for virus adsorption. Then the inoculum was removed and the cells were incubated for various periods with Eagle MEM supplemented with 5\% fetal calf serum and 2\% Sephadex G-200. At intervals, the cells were washed with phosphate buffered saline ( $\mathrm{pH} 7.4, \mathrm{PBS}$ ) and fixed with cold acetone for $20 \mathrm{~min}$. The cells were first reacted with anti-rabies virus mouse ascitic fluid for $60 \mathrm{~min}$ at $37 \mathrm{C}$. After washing with PBS 3 times, the cells were then stained with biotinyl-anti-mouse immunoglobulin (Ig) G goat serum (E. Y. Laboratories, Inc. CA, U. S. A.) at an appropriate dilution for $60 \mathrm{~min}$ at $37 \mathrm{C}$ and finally stained with advidin conjugated with peroxidase (E. Y Laboratories, Inc. CA, U. S. A.) for $60 \mathrm{~min}$ at $37 \mathrm{C}$. Peroxidase reaction was done with $\mathrm{H}_{2} \mathrm{O}_{2}$ and $3,3^{\prime}$-diamino benzidine tetrahydrochloride (Sigma Chemicals, MO, U. S. A.) as described by Graham and Karnovsky (1966). The slide was sealed with buffered glycerin and the stained foci were counted under an ordinary light microscope.

Kinetics of virus neutralization: Anti-rabies virus mouse ascitic fluid was pretreated 
with $25 \%$ kaolin suspension as described by Smith et al., (1973). Virus suspension containing $10^{6}$ focus-forming unit (FFU) $/ 0.1 \mathrm{ml}$ was mixed with an equal volume of serially diluted anti-rabies virus mouse ascitic fluid and incubated at $36 \mathrm{C}$ in water bath. At intervals of incubation, $0.2 \mathrm{ml}$ of the mixture were taken and diluted immediately one hundred fold and kept in ice. The samples were then inoculated onto the cell monolayers in microslide culture chambers and assayed for the infectivity of surviving virus. Control virus suspension with virus diluent only was treated similarly.

\section{Results}

Formation of foci: Development of infected foci on CER cells by rabies virus was examined. Cell monolayers were infected with approximately $200 \mathrm{FFU}$ of the virus and incubated. At intervals, samples of the slides were taken and processed for BAP staining and the number of foci (Fig. 2) was counted. As shown in Fig. 3,

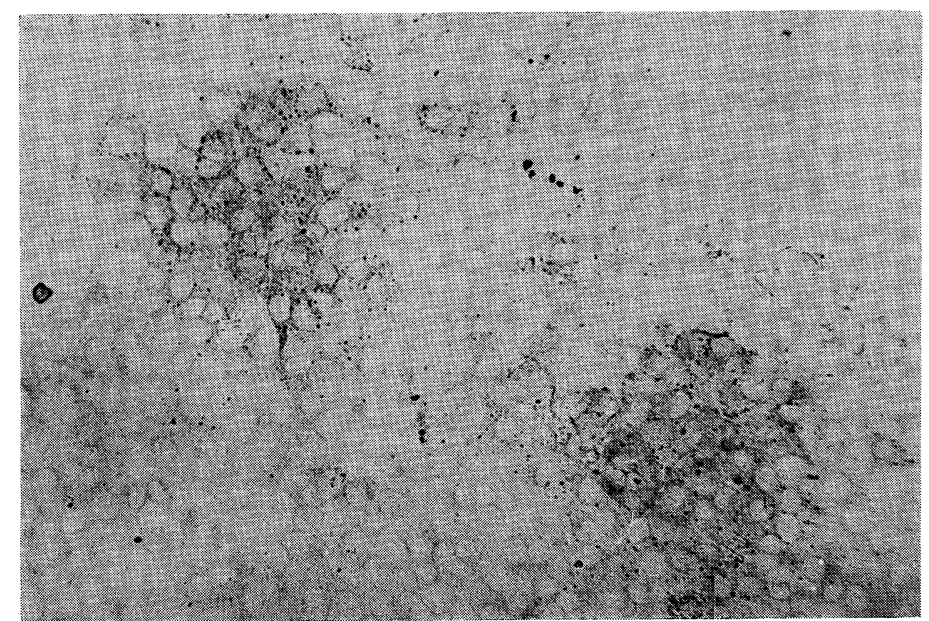

Figure 2 Stained foci of rabies virus-infected CER cells by biotin-avidinperoxidase (BAP) technique.

the foci became countable at $16 \mathrm{hr}$ after infection. The number of foci increased threreafter until $32 \mathrm{hr}$ after infection and reached a maximum although the size of focus increased even thereafter and became uncountable at $40 \mathrm{hr}$ because of the combinations with adjacent foci. From this observation, the number of foci was counted after $32 \mathrm{hr}$ of incubation in the following experiments.

Relationship between the number of foci and virus dilution was next examined. Aliquots of serial twofold dilutions of appropriately diluted virus were inoculated on the cells and the number of foci was counted at $32 \mathrm{hr}$ after infection. Fig. 4 shows a linear relationship between the logarithms of the virus dilution and the number of foci per chamber, indicating that one focus was produced by one infectious particle of virus. 


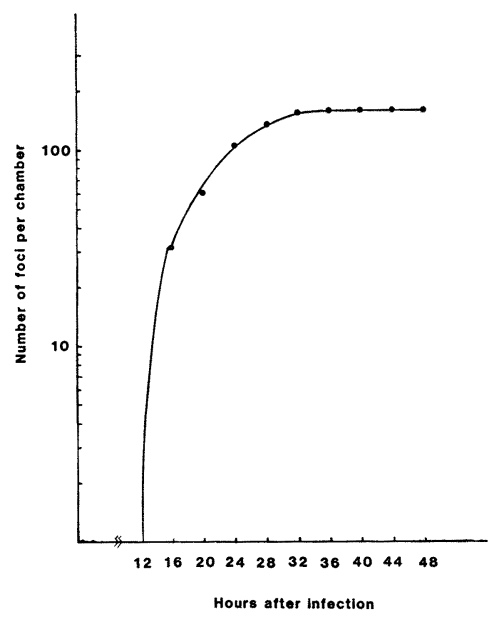

Figure 3 Development of foci on CER cells infected with rabies virus as measured by the BAP technique.

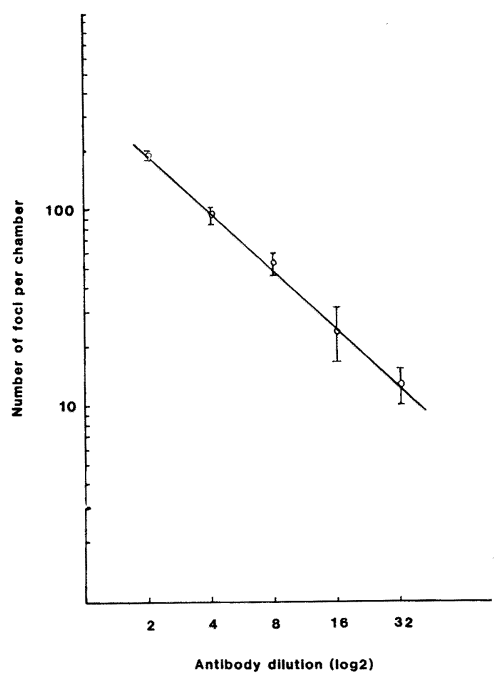

Figure 4 Linear response of rabies virus focus formation in CER cells. Serial twofold dilution of virus was done with virus diluent. Fifty microliters of each dilution was inoculated onto the CER cells and the number of foci was counted after $32 \mathrm{hr}$ of incubation. The average numbers of foci in triplicate chambers were shown.

Simultaneous experiments with FA staining technique showed an identical dose response of fluorescent focus formation by rabies virus (Data not shown).

Kinetics of virus neutralization: The optimum incubation period of virus-antibody mixtures for measuring neutralizing antibody was determined at 36 C. Fig. 5 shows the results of the kinetic studies examined with $10^{6} \mathrm{FFU} / \mathrm{ml}$ of virus and different dilutions of anti-rabies virus mouse ascitic fluid. Although the virus was neutralized by more than $90 \%$ after $15 \mathrm{~min}$ of incubation, the neutralization progressed gradually until $90 \mathrm{~min}$ of incubation and completed in each dilution of ascitic fluid. Only $28 \%$ of the virus was inactivated after $2 \mathrm{hr}$ of incubation.

Thus, the incubation of $90 \mathrm{~min}$ at $36 \mathrm{C}$ was selected as the conditions of the following neutralization tests.

Determination of neutralizing antibody titers of anti-rabies virus mouse ascitic fluid: Two lots of mouse ascitic fluid were diluted by twofold dilution starting 1:800. Each dilution was incubated with an equal volume of virus suspension containing $400 \mathrm{FFU}$ of virus $/ 0.1 \mathrm{ml}$ and incubated at $36 \mathrm{C}$ for $90 \mathrm{~min}$. Fifty $\mu l$ of the mixtures were then inoculated onto the cells and assayed for surviving virus by BAP technique. The percent of focus inhibition was obtained by dividing the number of foci in test samples by the number of foci in control virus sample which was done in parallel only with the medium. 


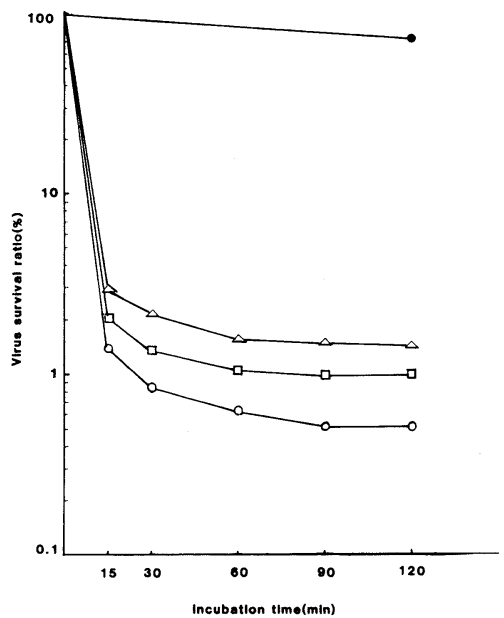

Figure 5 Kinetics of neutralization of rabies virus. Rabies virus containing $10^{6}$ $\mathrm{FFU} / \mathrm{m} l$ was mixed with an equal volume of anti-rabies virus mouse ascitic fluid diluted $1: 250(\mathrm{O}-\mathrm{O})$, $1: 500(\square-\square)$, or $1: 1000(\triangle-\triangle)$ and incubated at $36^{\circ} \mathrm{C}$. Virus control was incubated with virus diluent only. At intervals of incubation, two hundred microliters of the mixture were taken and the infectivity of surviving virus was assayed.

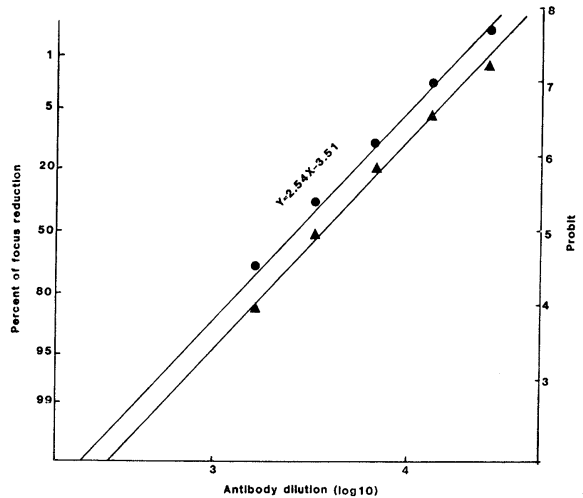

Figure 6 Neutralization of rabies virus with two preparations of anti-rabies virus mouse ascitic fluid.

The percent of focus reduction was transformed into probit and a probit regression line $(\mathrm{Y}=\mathrm{a}+\mathrm{bX})$ was calculated against the logarithms of antibody dilution $(\mathrm{X})$. As shown in Fig. 6, probit of the percent of focus reduction fitted to the obtained probit regression lines at various concentrations of antibodies. The slopes of the probit regression lines of two preparations of anti-rabies virus mouse ascitic fluid were same. Thus the fifty percent focus reduction titer of neutralizing antibody of a given serum can be estimated from the probit regression line.

\section{Discussion}

An immuno-peroxidase (BAP) technique was applied to the rapid titration of rabies virus infectivity and virus neutralization test. The results indicated that the BAP technique can be replaced by FA technique for the titration of rabies virus infectivity. This application to virus neutralization test would provide a new method especially for determining neutralizing antibody titers of a large number of specimens since immuno-peroxidase staining method has several advantages over the FA technique as mentioned previously. 


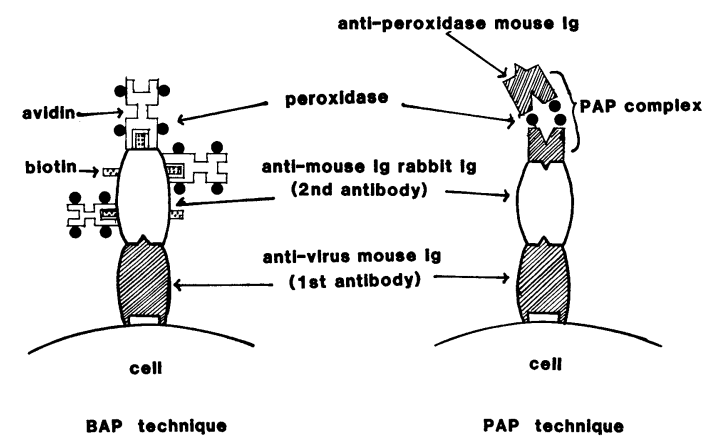

Figure 7 The principle of BAP staining technique and the comparison with PAP (peroxidase-anti-peroxidase) staining technique.

The principle of BAP technique (Fig. 7) is based on extremely high affinity of avidin (affinity constant, $10^{15} \mathrm{M}^{-1}$ ) to the biotin which is a vitamin with a molecular weight of 244 and derived from the diet and intestinal bacteria. Ig or proteins can be covalently coupled with many molecules of biotin without loss of biological activities of the proteins. Avidin is a basic glycoprotein of approximately 68000 of molecular weight which is present in eggs. Each avidin molecule possesses four binding sites for biotin while each biotin molecule is capable of binding to only one avidin molecule (Moss et al., 1971). The binding is extremely resistant to dissociation. One molecule of avidin can be conjugated with more than two molecules of horseradish peroxidase.

Thus the use of antiviral Ig (first antibody), biotinyl anti-Ig serum (second antibody) and peroxidase conjugated avidin for the staining of viral antigens in the cells should provide higher sensitivity and specificity than the peroxidase-labelled antibody techniques or peroxidase-anti-peroxidase (PAP) staining technique as has been studied and proven by Guesdon et al. (1979). In addition, BAP technique has one more advantage over the PAP technique, i.e. the peroxidase conjugated avidin can be used to biotinyl anti-Ig prepared in any species of animals, while in PAP technique, PAP complex should be prepared each in corresponding animal to which antiviral serum (first antibody) is prepared (Fig. 7).

\section{References}

1) Benjamin, D. R. (1974): Rapid typing of herpes simplex virus strains using the indirect immunoperoxidase method, Appl. Microbiol., 28, 568-571

2) Buckley, S. M. \& Tignor, G. H. (1975): Plaque assay of rabies serogroup viruses in Vero cells, J. Clin. Microbiol., 1, 241-242

3) Gerna, G., Vasquez, A., McCloud, C. J. \& Chambers, R. W. (1976): The immunoperoxidase technique for rapid human cytomegalovirus identification, Arch. Virol., 50, 311-321

4) Graham, R. C., Jr. \& Karnovsky, M.J. (1966): The early stages of absorption of injected horseradish peroxidase in the proximal tubules of mouse kidney: ultrastructural cytochemistry by a new technique, J. Histochem. Cytochem., 14, 291-302

5) Guesdon, J., Ternynck, T. \& Avrameas, S. (1979): The use of avidin-biotin interaction in immunoenzymatic techniques, J. Histochem. Cytochem., 27, 1131-1139 
6) Hahon, N., Simpson, J. \& Eckert, H. L. (1975): Assessment of virus infectivity by the immunofluorescent and immunoperoxidase techniques, J. Clin. Microbiol., 1, 324-329

7) Hsu, S. \& Raine, L. (1982): Versatility of biotin-labelled lectins and avidin-biotin-peroxidase complex for localization of carbohydrate in tissue sections, J. Histochem. Cytochem., 30, 157-161

8) Matsumoto, S. \& Kawai, A. (1969): Comparative studies on development of rabies virus in different host cells, Virology, 39, 449-459

9) Miller, M. H., Karnovsky, M. J. \& Diamandopoulos, G. Th. (1974): An improved immunoperoxidase technique for identifiting SV-40 V and T antigens by light microscopy, Proc. Soc. Exp. Biol. Med., 146, 432-437

10) Moss, J. \& Lane, M. D. (1971): The biotin dependent enzymes, Adv. Enzymol., 35, 321-347

11) Okuno, Y., Sasao, F., Fukunaga, T. \& Fukai, K. (1977): An application of PAP (peorxidaseanti-peroxidase) staining technique for the rapid titration of dengue virus type 4 infectivity, Biken J., 20, 29-33

12) Okuno, Y., Fukunaga, T., Srisupaluck, S. \& Fukai, K. (1979): A modified PAP (peroxidaseanti-peroxidase) staining technique using sera from patients with dengue hemorrhagic fever (DHF): 4 step PAP staining technique, Biken J., 22, 131-135

13) Schneider, L. (1973): Cell monolayer plaque test; in Kaplan and Koprowski Laboratory techniques in rabies, pp. 339-342

14) Sedwick, W. D. \& Wiktor, T. J. (1967): Reproducible plaquing system for rabies, lymphocytic choriomeningitis, and other ribonucleic acid viruses in BHK-21/13S agarose suspensions, J. Virol., 1, 1224-1226

15) Smith, A. L., Tignor, G. H., Mifune, K. \& Motohashi, Y. (1977): Isolation and assay of serogroup viruses in CER cells, Intervirol., 8, 92-99

16) Smith, J. S., Yager, P. A. \& Baer, G. M. (1973): A rapid reproducible test for determining rabies neutralizing antibody, Bull. W. H. O., 48, 535-541

17) Strating, A., Mitzel, J. R. \& Slater, E. A. (1975): Plaque assay of rabies virus on porcine kidney cell monolayers, J. Clin. Microbiol., 2, 126-128

18) Warnke, R. \& Levy, R. (1980): Detection of T and B cell antigens with hybridoma monoclonal antibodies: A biotin-avidin-horseradish peroxidase method, J. Histochem. Cytochem., 28, 771-776

19) Yoshino. K., Taniguchi, S. \& Arai, K. (1966): Plaque assay of rabies virus in chick embryo cells, Arch. ges. Virusforsch., 18, 370-373

$$
\begin{gathered}
\text { ビオチン，アビジン，ペルオキシダーゼ法（免疫酵素抗体法） } \\
\text { による狂犬病ウイルス感染価の迅速測定法と } \\
\text { そのウイルス中和抗体測定への応用 }
\end{gathered}
$$

$$
\text { 七 條 明 } \text { 久 }^{1} \cdot \text { 三 舟 求真人 }{ }^{1} \cdot \text { 林 慧 } \text { 君 }^{2}
$$

マイクロスライドチェンバーを使用し, 免疫酵素抗体法（ビオチン, アビジン, ペロキシダーゼ法） による狂犬病ウイルス感染価およびウイルス中和抗体価の迅速測定法を確立した。この方法は迅速で あるのみならず，感度，再現性す優れており，従来から使用されている螢光抗体法に代って狂犬病の 迅速診断あるいは血清疫学に有用な新らしい方法となるあのである。

\section{1 大分医科大学医学部 微生物学講座 2 長崎大学熱帯医学研究所ウイルス学部門}

